\title{
The Effects of Vitamin A Compounds on Hyaluronic Acid Released from Cultured Rabbit Corneal Epithelial Cells and Keratocytes
}

\author{
Hiroshi TosHIDA ${ }^{1}$, Nobuhito TABUCHI ${ }^{2,3}$, Daisuke KoIKE ${ }^{3}$, Misao KoIDE ${ }^{3}$, \\ Keikichi SugIYAma $^{4,5}$, Kiyoo NAKAYASU ${ }^{2}$, Atsushi KANAI ${ }^{2}$ and Akira MuraKAmI ${ }^{2}$ \\ ${ }^{1}$ Department of Ophthalmology, Juntendo University Shizuoka Hospital, 1195, Nagaoka, Izunokuni, \\ Shizuoka 410-2295, Japan \\ ${ }^{2}$ Department of Ophthalmology, Juntendo University School of Medicine, 2-1-1, Hongo, \\ Bunkyo-ku, Tokyo 113-8421, Japan \\ ${ }^{3}$ Pharmaceutical Research Laboratories No. 1, Research and Development Headquarters, \\ Lion Corporation, 100, Tajima, Odawara, Kanagawa 256-0811, Japan \\ ${ }^{4}$ Research and Development Headquarters, Lion Corporation, 7-2-1, Hirai, \\ Edogawa-ku, Tokyo 132-0035, Japan \\ ${ }^{5}$ Ritsumeikan Global Innovation Research Organization, Ritsumeikan University, 1-1-1, \\ Noji-higasi, Kusatsu, Shiga 525-8577, Japan \\ (Received November 4, 2011)
}

\begin{abstract}
Summary A role of vitamin A in the synthesis of hyaluronic acid by skin cells is well known. Hyaluronic acid is produced by corneal epithelial cells and keratocytes in the eye. We investigated whether rabbit corneal epithelial cells and keratocytes release hyaluronic acid after exposure to vitamin A compounds. Rabbit corneal epithelial cells and keratocytes were inoculated with RCGM2 medium and incubated at $37^{\circ} \mathrm{C}$ under $5 \% \mathrm{CO}_{2}$ in air for $24 \mathrm{~h}$. The medium was then replaced with medium containing $0.1,1,10$, or $100 \mu \mathrm{M}$ retinoic acid or retinol palmitate (VApal) and incubated for another $48 \mathrm{~h}$. Hyaluronic acid release from both corneal epithelial cells and keratocytes during culture was increased by retinoic acid at the lower concentration of $0.1 \mu \mathrm{M}$ and $1 \mu \mathrm{M}$ determined with a sandwich binding protein assay kit. However, it was significantly decreased at the higher concentrations of $10 \mu \mathrm{M}$ and $100 \mu \mathrm{M}$, and the cell count determined with a Neutral Red assay kit was also decreased at these concentrations. On the other hand, hyaluronic acid release from corneal epithelial cells during culture was increased by VApal at the lower concentration of $0.1 \mu \mathrm{M}$ and $1 \mu \mathrm{M}$, but there was no significant difference in the cell count for either corneal epithelial cells or keratocytes in the presence of VApal at any concentration. In conclusion, it is suggested that vitamin A stimulates the release of hyaluronic acid from cultured rabbit corneal epithelial cells and keratocytes. Key Words vitamin A, cornea, wound healing, dry eye, cytotoxicity
\end{abstract}

Vitamin A deficiency has long been known to induce corneal/conjunctival epithelial disorders and keratosis. Vitamin A is therefore considered to be essential for maintenance of ocular surface health and some clinicians have reported its efficacy when used to treat certain corneal disorders (1-4). Promotion of the healing of injury by vitamin A has also been reported in a rabbit model of corneal epithelial detachment (5). The actions of vitamin A include improving keratosis of the corneal/ conjunctival epithelium and increasing the conjunctival goblet cell count. We have previously reported that promotion of mucin production by the healing conjunctival epithelium could be a possible mechanism of action for vitamin A (6).

A role of vitamin A in the synthesis of hyaluronic acid by skin cells has also been reported (7-14). Hyaluronic acid is produced by corneal epithelial cells and keratocytes in the eye, and is known to be one of the factors

E-mail: toshida@juntendo.ac.jp that promotes the healing of corneal injuries. Accordingly, we investigated whether cultured rabbit corneal epithelial cells and keratocytes release hyaluronic acid after exposure to vitamin A compounds, as has been reported for epidermal keratinocytes in skin (7-14).

Two different vitamin A derivatives were investigated, which were retinoic acid (a potent vitamin A derivative that promotes hyaluronic acid synthesis by cultured dermal cells) and retinol palmitate (VApal; an ester of vitamin A with relatively high stability among the vitamin A group that is expected to find clinical application in the ophthalmology field).

\section{MATERIALS AND METHODS}

Study compounds. Retinoic acid (Sigma-Aldrich Corporation, St. Louis, USA) and retinol palmitate (VApal) (DMS Nutrition Japan, Inc., Tokyo, Japan) were used as the vitamin A derivatives. Each agent was dissolved in $99.5 \%$ ethanol at a concentration of $10 \mathrm{mM}$, and then was diluted with RCGM2 medium (Kurabo Industries, 
Ltd., Osaka, Japan; a serum-free medium for culture of rabbit corneal epithelial cells) to prepare $0.1,1,10$, and $100 \mu \mathrm{M}$ solutions.

Animal experimental protocol. This study was performed in accordance with the guidelines for animal experimentation at Juntendo University School of Medicine and with the Association for Research in Vision and Ophthalmology (ARVO) Statement for the use of animals in Ophthalmic and vision research.

Preparation of corneal epithelial cells. Corneal epithelial cells were purchased as a frozen normal rabbit corneal epithelial cell suspension $\left(1 \times 10^{6}\right.$ cells $\left./ \mathrm{mL} / \mathrm{vial}\right)$ for secondary culture (NRCE2; Kurabo Industries) (15, 16). After thawing the frozen suspension, the cells were incubated with RCGM2 medium for $5 \mathrm{~d}$ at $37^{\circ} \mathrm{C}$ under $5 \% \mathrm{CO}_{2}$ in air. Then cells were collected by treatment with trypsin and culture was repeated. Cells from the third passage (suspension) were used for the present experiments.

RCGM2 is a serum-free medium (basal medium) with a culture additive $(5 \mu \mathrm{g} / \mathrm{mL}$ insulin, $10 \mathrm{ng} / \mathrm{mL}$ EGF, $0.5 \mu \mathrm{g} / \mathrm{mL}$ hydrocortisone, $50 \mu \mathrm{g} / \mathrm{mL}$ gentamicin, $50 \mathrm{ng} / \mathrm{mL}$ amphotericin $\mathrm{B}$, and $0.4 \%$ bovine pituitary extract).

Preparation of keratocytes. Japanese white rabbits (Japan SLC, Inc., Shizuoka, Japan) weighing approximately $3 \mathrm{~kg}$ were sacrificed with an overdose of pentobarbital sodium (Nembutal, Dainippon Pharmaceutical Corporation, Ltd., Osaka, Japan). Then the corneas were harvested and the endothelial layer with the epithelium and Descemet's membrane was detached by using a spatula. The specimens of corneal parenchyma thus obtained were treated with $0.05 \%$ collagenase for $1 \mathrm{~h}$ and centrifuged for $5 \mathrm{~min}$ at 2,000 rpm to collect keratocytes. Then these cells were cultured in minimal essential medium (MEM, GIBCO, Life Technologies, Carlsbad, CA, USA) containing 5\% fetal bovine serum (FBS) for five passages (the fifth generation of passage in culture) before use in the experiments (17).

Culture methods. Corneal epithelial cells and keratocytes were inoculated into 96-well microplates with RCGM2 medium at $2 \times 10^{4}$ cells/well and incubated at $37^{\circ} \mathrm{C}$ under $5 \% \mathrm{CO}_{2}$ in air for $24 \mathrm{~h}$. The microplate was covered with its lid during culture. After the medium was replaced with RCGM2 containing $0.1,1,10$, or $100 \mu \mathrm{M}$ retinoic acid or VApal, the cells were incu-

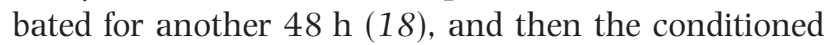
medium was harvested to measure the content (quantity released) of hyaluronic acid. After incubation, the cell count, cell viability, cytotoxicity, and cell proliferation were also determined.

Measurement of hyaluronic acid. The hyaluronic acid concentration of culture supernatant was determined with a sandwich binding protein assay kit (Chugai hyaluronic acid plate; Chugai Pharmaceutical Corporation, Ltd., Tokyo, Japan) according to the manufacturer's protocol. The assay was based on the specificity of a hyaluronic acid-binding protein isolated from bovine cartilage for hyaluronic acid (19).

After completion of incubation, $50 \mu \mathrm{L}$ of culture su- pernatant was collected from each well of the corneal epithelial cell and keratocyte cultures, and mixed with $500 \mu \mathrm{L}$ of reaction buffer. Then a $100 \mu \mathrm{L}$ aliquot of each mixture was dispensed into a 96-well microplate (96 HABP Coated Microwells), and the plate was shaken gently and let stand at room temperature for $1 \mathrm{~h}$. Next, the solution in each well was discarded and $300 \mu \mathrm{L}$ of washing solution was added to each well. After discarding the washing solution, each well was washed another three times. Subsequently, $100 \mu \mathrm{L}$ of enzyme solution (HRP-conjugated hyaluronic acid-binding protein (HABP)) was added to each well, the plate was shaken gently and let stand at room temperature for $30 \mathrm{~min}$, and then was washed 4 times with washing solution. After $100 \mu \mathrm{L}$ of color solution (3,3',5,5'-tetramethylbenzine) was added to each well, the plate was shaken gently and was let stand in the dark at room temperature for $30 \mathrm{~min}$. Finally, the stop solution $(100 \mu \mathrm{L})$ was added and mixed well, followed by measurement of the absorbance at $450 \mathrm{~nm}$ with a microplate reader. The concentration of hyaluronic acid was determined from a standard curve. Data were then presented in terms of $\mathrm{ng} / \mathrm{mL}$ of culture medium.

Determination of the cell count. The cell count (viability, cytotoxicity, and proliferation) was determined by using a commercially available Neutral Red (NR) assay kit (NR Reagent set; Kurabo Industries, Ltd.) (20-23). This assay is an easy and repeatable method of counting cells that was developed by Borenfreund and Puerner $(20,21)$. It uses a water-soluble dye (3-amino-7-dimethylamino-2-methyl-phenazine hydrochloride (NR)), which crosses the plasma membrane and is incorporated into the lysosomes of living cells. As the incorporation of NR is proportional to the number of viable cells, the viable cell count can be indirectly determined.

In brief, cells were cultured with NR according to the manufacturer's instructions and the number of viable cells was determined from the uptake of dye.

After culture of corneal epithelial cells and keratocytes was completed, the culture medium was replaced by RCGM 2 containing $50 \mu \mathrm{g} / \mathrm{mL}$ of NR per well, and the cells were incubated for another $3 \mathrm{~h}$. After discarding the culture medium with NR from each well, $200 \mu \mathrm{L}$ of formalin solution containing $1 \%$ calcium chloride was added to fix the cells, followed by washing and extraction of NR from viable cells with $200 \mu \mathrm{L}$ of ethanol containing $1 \%$ acetic acid (at room temperature $20 \mathrm{~min}$ ). Subsequently, the absorbance was measured at $540 \mathrm{~nm}$ with a microplate reader. Cell counts were expressed as a percentage of the NR incorporation by cells cultured without treatment (control).

Statistical analysis. The Mann-Whitney $U$ test was performed to compare the solvent control culture with each concentration of vitamin $\mathrm{A}(0.1,1,10$, and $100 \mu \mathrm{M})$ for both hyaluronic acid release and the cell count. All statistical tests were two-sided and significance was accepted at $p<0.05$. Data were shown as the mean \pm standard deviation. 


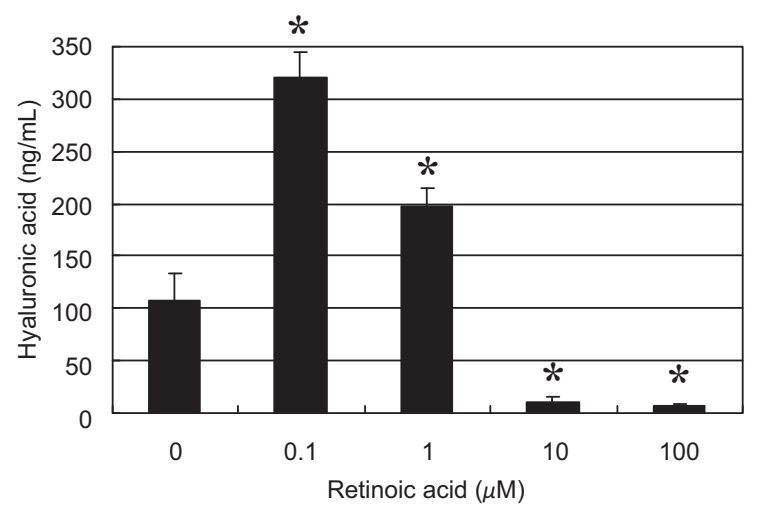

Fig. 1A. Hyaluronic acid release after the addition of retinoic acid or the solvent alone to corneal epithelial cells. Hyaluronic acid release was significantly higher with retinoic acid at $0.1 \mu \mathrm{M}$ and $1 \mu \mathrm{M}$. However, hyaluronic acid release was significantly lower after incubation with $10 \mu \mathrm{M}$ and $100 \mu \mathrm{M}$ retinoic acid compared with solvent alone. Values represent means \pm SD from four individual wells. ${ }^{*} p<0.05$ (Mann-Whitney's $U$ test).

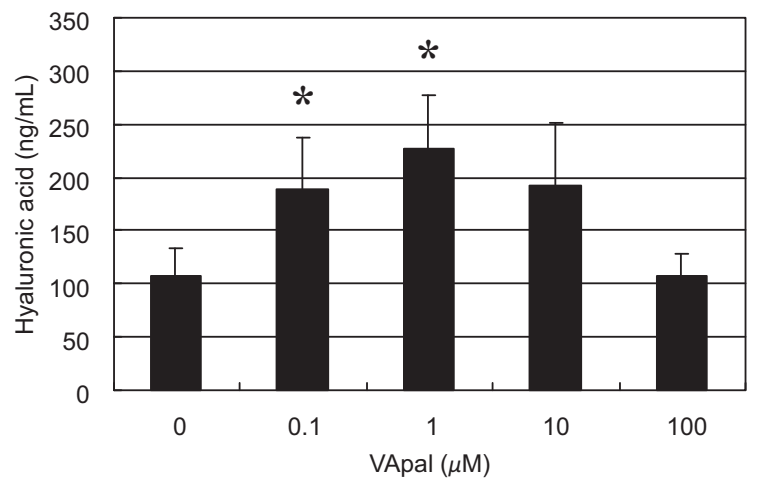

Fig. 1B. Hyaluronic acid release after the addition of VApal or the solvent alone to corneal epithelial cells. Hyaluronic acid release was significantly higher after incubation with $0.1 \mu \mathrm{M}$ and $1 \mu \mathrm{M}$ VApal compared with solvent alone. Values represent means \pm SD from four individual wells. ${ }^{*} p<0.05$ (Mann-Whitney's $U$ test).

\section{RESULTS}

\section{Hyaluronic acid release}

Figure 1A shows hyaluronic acid release after the addition of retinoic acid or the solvent alone to corneal epithelial cells. Hyaluronic acid release was $107.8 \pm 25.5 \mathrm{ng} / \mathrm{mL}$ after addition of the solvent alone, whereas it was significantly higher with $0.1 \mu \mathrm{M}$ retinoic acid $(321.0 \pm 23.8 \mathrm{ng} / \mathrm{mL}, p<0.05)$ and $1 \mu \mathrm{M}$ retinoic acid $(198.2 \pm 16.7 \mathrm{ng} / \mathrm{mL}, \quad p<0.05)$. However, hyaluronic acid release was significantly lower after incubation with $10 \mu \mathrm{M}$ and $100 \mu \mathrm{M}$ retinoic acid compared with solvent alone $(p<0.05)$.

Figure 1B shows hyaluronic acid release after addition of VApal or solvent alone to corneal epithelial cells. In the presence of VApal at concentrations of $0.1 \mu \mathrm{M}$ and $1 \mu \mathrm{M}$, the hyaluronic acid release was $189.2 \pm 48.3 \mathrm{ng} /$

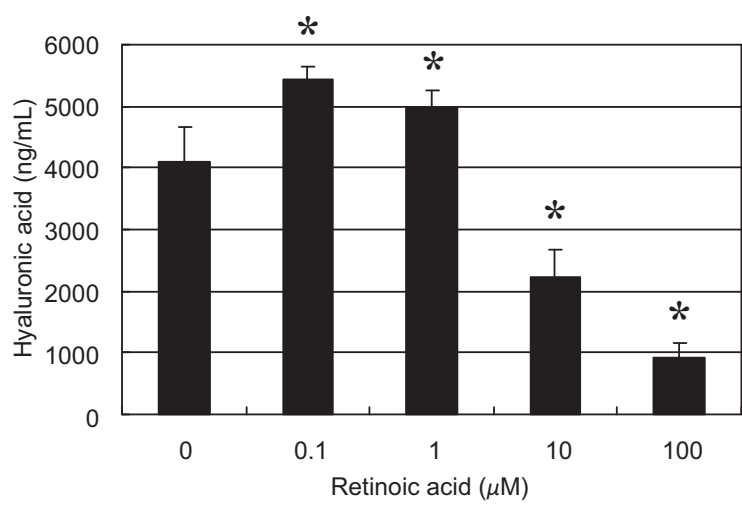

Fig. 2A. Hyaluronic acid release after the addition of retinoic acid or the solvent alone to keratocytes. Hyaluronic acid release was significantly higher with retinoic acid at $0.1 \mu \mathrm{M}$ and $1 \mu \mathrm{M}$. However, hyaluronic acid release was significantly reduced by $10 \mu \mathrm{M}$ and $100 \mu \mathrm{M}$ retinoic acid compared with solvent alone. Values represent means \pm SD from four individual wells. ${ }^{*} p<0.05$ (Mann-Whitney's $U$ test).

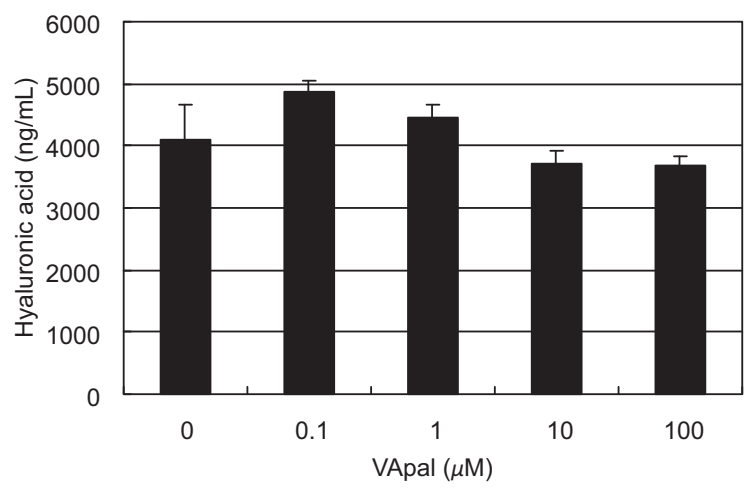

Fig. 2B. Hyaluronic acid release after the addition of VApal or the solvent alone to keratocytes. No statistically significant differences in hyaluronic acid release were observed in the presence of VApal at any concentration. Values represent means \pm SD from four individual wells.

$\mathrm{mL}(p<0.05)$ and $226.9 \pm 50.6 \mathrm{ng} / \mathrm{mL}(p<0.05)$ respectively, with both concentrations being significantly higher compared with solvent alone (107.8 $\pm 25.5 \mathrm{ng} /$ $\mathrm{mL})$. The highest hyaluronic acid release was obtained with $1 \mu \mathrm{M}$ VApal, while no significant difference was observed with VApal at $10 \mu \mathrm{M}$ or $100 \mu \mathrm{M}$.

After addition of retinoic acid to keratocytes, maximum hyaluronic acid release $(5,433.6 \pm 206.9 \mathrm{ng} /$ $\mathrm{mL})$ was found in the presence of $0.1 \mu \mathrm{M}$ retinoic acid $(p<0.05)$, whereas the hyaluronic acid level was $4,104.4 \pm 571.8 \mathrm{ng} / \mathrm{mL}$ after incubation with solvent alone (Fig. 2A). Release was also significantly increased $(4,992.0 \pm 251.9 \mathrm{ng} / \mathrm{mL}, p<0.05)$ by incubation with $1 \mu \mathrm{M}$ retinoic acid, but was significantly reduced by incubation with $10 \mu \mathrm{M}$ and $100 \mu \mathrm{M}$ retinoic acid compared with solvent alone (both $p<0.05$ ).

No statistically significant differences in hyaluronic acid release were observed in the presence of VApal at any concentration (Fig. 2B). 


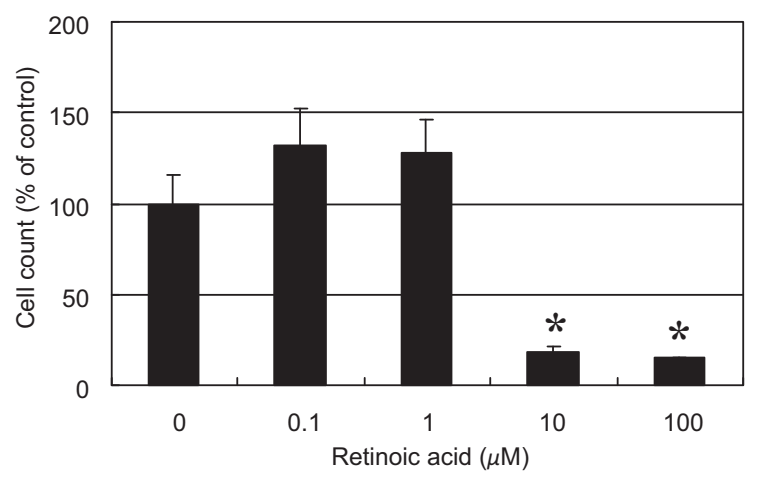

Fig. 3A. Cell count after the addition of retinoic acid or the solvent alone to corneal epithelial cells. Cell count was significantly reduced by $10 \mu \mathrm{M}$ and $100 \mu \mathrm{M}$ retinoic acid compared with solvent alone. Values represent means \pm SD from four individual wells. ${ }^{*} p<0.05$ (Mann-Whitney's $U$ test). (The results are expressed as percentage of the control cultures.)

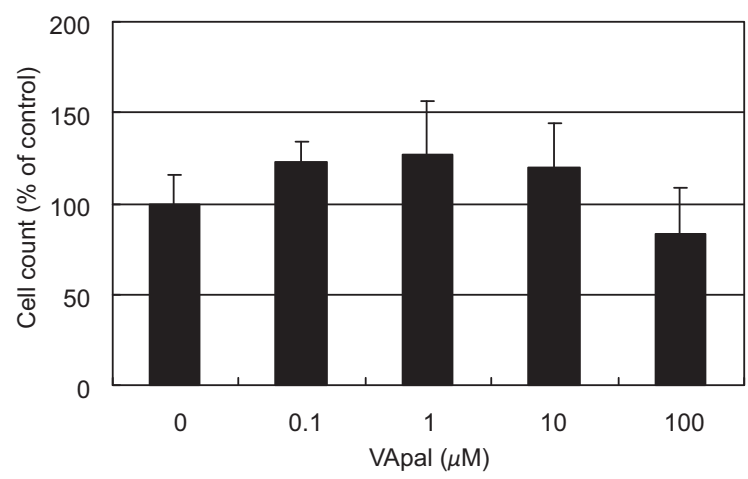

Fig. 3B. Cell count after the addition of VApal or the solvent alone to corneal epithelial cells. No statistically significant differences in the cell count were observed in the presence of VApal at any concentration. Values represent means \pm SD from four individual wells. (The results are expressed as percentage of the control cultures.)

\section{Cell count}

Although no statistically significant differences in the cell count were observed for cultured corneal epithelial cells or keratocytes after addition of retinoic acid at concentrations up to $1 \mu \mathrm{M}$ (Figs. 3A and 4A), the cell count was lower when corneal epithelial cells were cultured at $10 \mu \mathrm{M}(p<0.05)$ and when both types of cells were cultured at $100 \mu \mathrm{M}$ (both $p<0.05$ ) (Figs. 3A and 4A).

In contrast, no significant differences in the cell count were observed for cultured corneal epithelial cells or keratocytes after addition of VApal (Figs. 3B and 4B).

\section{DISCUSSION}

The ocular surface is similar to the skin in a number of ways. For example, it is constantly exposed to various environmental factors, such as ultraviolet radiation, foreign materials, and trauma. Corneal epithelial cells synthesize hyaluronic acid, as do epidermal keratinocytes $(24,25)$. Increased hyaluronic acid synthesis and release by epidermal keratinocytes in the presence

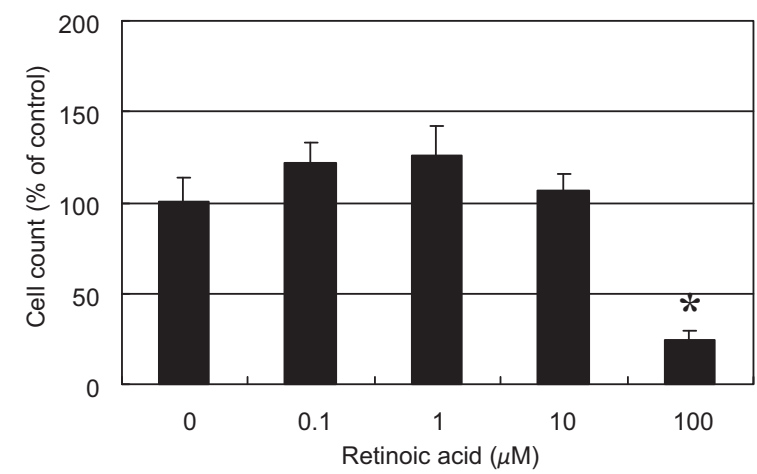

Fig. 4A. Cell count after the addition of retinoic acid or the solvent alone to keratocytes. Cell count was significantly reduced by $100 \mu \mathrm{M}$ retinoic acid compared with solvent alone. Values represent means \pm SD from four individual wells. ${ }^{*} p<0.05$ (Mann-Whitney's $U$ test). (The results are expressed as percentage of the control cultures.)

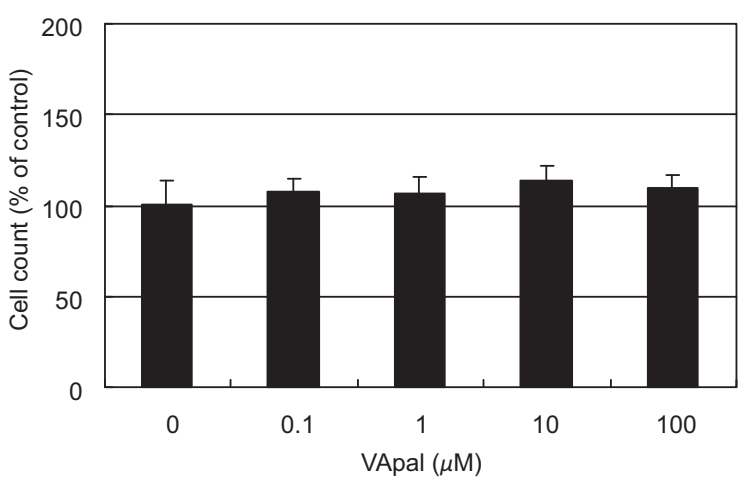

Fig. 4B. Cell count after the addition of VApal or the solvent alone to keratocytes. No statistically significant differences in the cell count were observed in the presence of VApal at any concentration. Values represent means \pm SD from four individual wells. (The results are expressed as percentage of the control cultures.)

of vitamin A was first reported in the early 1980s (11). The results of the present study showed that vitamin A promotes hyaluronic acid release by corneal epithelial cells and keratocytes, as has been demonstrated in previous studies of epidermal keratocytes.

The existence of retinol-binding protein, retinyl ester hydrolase and retinyl palmitate hydrolase in mammals is known (26-28). However, the mechanism of action of vitamin A is yet to be elucidated. The mechanisms of hyaluronic acid production/secretion by retinoic acid and VApal in the cornea are also not known. It is known that hyaluronic acid synthetase (HAS) is found not only in the skin but also in the cornea (29). Extensive studies report that in the skin, hyaluronic acid production is promoted by beta-carotene, retinol, retinal and retinoic acid via HAS3 gene expression $(30,31)$ and by retinyl retinoate via HAS2 gene expression $(32,33)$. HA production is thought to be promoted through nuclear receptors of metabolized and converted retinoic acid (HAS gene expression) (30-33).

It has been reported that VApal is converted into reti- 
nol in the skin of mammals and humans $(34,35)$ and that retinol is metabolized and converted into retinal and retinoic acid $(36,37)$. Considering that retinol is converted into retinoic acid in cultured corneal epithelial cells and in rabbit corneas, as it also is in skin (38, 39 ), it is reasonable to assume that in our study, hyaluronic acid production by retinoic acid and VApal in the cornea was promoted through nuclear receptors of retinoic acid and HAS gene expression. A role of epidermal growth factor receptor signaling was also reported (9).

The mechanism of action of vitamin A on corneal epithelial cells is also unknown, but we previously found that improvement of the Rose bengal score preceded improvement of the fluorescein score or repair of keratoconjunctival epithelial damage following administration of VApal during healing of $n$-heptanol-induced wounds to the ocular surface (6). It therefore seems possible that repair of the mucin layer takes place before repair of keratoconjunctival epithelial damage when vitamin A promotes healing of corneal/conjunctival wounds. It could also be suggested that vitamin A acts after repair of the mucin layer because its effect is mediated by enhanced hyaluronic acid release. However, it is still unknown whether vitamin A promotes the secretion and production of mucin by corneal epithelial cells, as it does in the case of conjunctival cells, so further studies are required.

Hyaluronic acid is secreted in very small quantities in corneal epithelial cells and keratocytes (24), but produced in large quantities after corneal injury such as trauma or excimer laser irradiation $(40,41)$. Fitzsimmons et al. (41) performed keratectomy from the corneal epithelium to the superficial layer of the parenchyma of rabbits using an excimer laser and found that the hyaluronic acid levels on the 8th and 21st days were $7.3 \mu \mathrm{g} / \mathrm{g}$ and $14 \mu \mathrm{g} / \mathrm{g}$, respectively. These levels are approximately similar to the hyaluronic acid level of $4,104.4 \pm 571.8 \mathrm{ng} / \mathrm{mL}$ in our study, which was measured in cultured corneal keratocytes. In contrast, the level of hyaluronic acid in cultured corneal epithelial cells was one order of magnitude lower. The reason for this difference is not known. While injury to corneal epithelial cells is rapidly repaired due to their high capacity to divide and migrate, injury to corneal parenchyma is more severe and, although keratocytes cannot divide as rapidly as epithelial cells, the corneal keratocytes are activated and converted into myofibroblasts during injury and they are assumed to synthesize glycosaminoglycans such as hyaluronic acid and collagen. This is supported by Asari et al. (42), who performed immunohistological staining using anti-hyaluronic acid antibodies in rabbits with $n$-heptanol-induced corneal injury. They reported that while the injury in corneal epithelium healed within $3 \mathrm{~d}$, hyaluronic acid was detected until the 28th day after injury in the corneal epithelium, and until the 56th day in the corneal parenchyma. Based on these findings, it is assumed that because injury to the corneal parenchyma is more invasive than that to the corneal epithelium, hyaluronic acid is produced as a biological reaction more in the corneal parenchyma than in the epithelium.

Corneal wound healing is thought to involve a 3-step mechanism: (1) adherence, extension, and transfer of epithelial cells; (2) proliferation of epithelial cells; and (3) differentiation of epithelial cells (43). In the present study, vitamin A did not promote the proliferation of cells. However, VApal promotes the production of not only hyaluronic acid but also mucin by cultured conjunctival tissue $(44,45)$. Therefore, ocular administration of VApal may improve epithelial damage to the cornea/conjunctiva in patients with conditions such as dry eyes through promotion of healing via the adherence, extension, migration of epithelial cells, as well as by stabilization of the tear film.

In the present study, retinoic acid and VApal showed different effects on corneal epithelial cells, although both are derivatives of vitamin A. Hyaluronic acid release by corneal epithelial cells was increased in the presence of both compounds over the concentration range of 0.1 to $1 \mu \mathrm{M}$, but hyaluronic acid release and the cell count were reduced by retinoic acid at higher concentrations. This finding might represent a manifestation of the cytotoxicity of vitamin A, which has been reported previously $(1,2,46)$. After culture for $48 \mathrm{~h}$ with a high concentration of VApal, however, there was low cytotoxicity compared with the effect of retinoic acid. On the other hand, VApal only increased the release of hyaluronic acid at low concentrations, so higher concentrations may have caused slight cell damage or dysfunction that did not lead to a decrease in the cell count.

VApal promoted hyaluronic acid release by cultured corneal epithelial cells at concentrations between 0.1 and $1 \mu \mathrm{M}$. When VApal eye drops $(1,000 \mathrm{IU} / \mathrm{mL})$ were administered to animals (6), the concentration in the cornea was calculated to be $1.04 \mu \mathrm{M}$, assuming that the ocular transfer rate was $0.1 \%$. This concentration is comparable with those tested in the present study. Cytotoxicity of retinoic acid for rabbit corneal epithelial cells was observed at $10 \mu \mathrm{M}$ or higher concentrations in the present study, whereas it was seen at concentrations of 6 to $30 \mu \mathrm{M}$ in a previous study of human epidermal keratinocytes (46). These results are similar. However, this similarity depends on the calculation of concentrations, but these levels may not be almost the same in vivo because of differences between the in vitro and in vivo settings. Moreover, it should be noted that the present results were obtained with cultured rabbit cells. Whether or not the same mechanisms operate in vivo remains unknown. However, the concentration of VApal, mentioned above $(1,000 \mathrm{IU} / \mathrm{mL})$, has been proved to be effective in humans as well as in rabbits, so the pharmacokinetics and in vivo effects may be similar in both species. On the other hand, when the cornea has been damaged, the concentration of vitamin $A$ in the cornea will increase because the barrier function will also be damaged. This is also a subject to pay attention to and study in the future. In this study, the amount of hyaluronic acid released into the conditioned medium was measured, but the amount of hyaluronic acid produced by the cells was not measured. Therefore, 
the effect of vitamin A on synthesis of hyaluronic acid released into the conditioned medium was measured, but the amount of hyaluronic acid is a subject to be studied in the future.

Numerous reports have been published concerning the efficacy of vitamin A for corneal epithelial disorders. Further research on vitamin A preparations is needed with respect to their effects on the ocular surface, mechanisms of action, and optimal concentration for safe clinical application to treat ocular surface disorders. Furthermore, the mechanism of the beneficial effects of vitamin A to mucin on corneal and epithelial cells (MUC1, 4 and 16) needs to be clarified $(45,47,48)$.

Vitamin A has the disadvantage of being unstable, with degradation caused by oxidation. Moreover, side effects including blepharoconjunctivitis have been caused by eye ointments containing retinoic acid. In contrast, the ester of vitamin A (retinol palmitate) used in this study can be considered to have a high potential for clinical application because of its relatively high stability among vitamin A derivatives and no reported side effects. However, there are still differences between rabbit cell cultures and human eyes in its mechanisms, efficacy and safety, and it is necessary to clarify them before clinical application.

\section{REFERENCES}

1) Wright P. 1985. Topical retinoic acid therapy for disorders of the outer eye. Trans Ophthalmol Soc UK 104: 869-874.

2) Soong HK, Martin NF, Wagoner MD, Alfonso E, Mandelbaum SH, Laibson PR, Smith RE, Udell I. 1988. Topical retinoid therapy for squamous metaplasia of various ocular surface disorders. A multicenter, placebocontrolled double-masked study. Ophthalmology 95: 1142-1146.

3) Ohashi Y, Watanabe H, Kinoshita S, Hosotani H, Umemoto M, Manabe R. 1988. Vitamin A eyedrops for superior limbic keratoconjunctivitis. Am J Ophthalmol 105: 523-527.

4) Kobayashi T, Tsubota K, Takamura E, Sawa M, Ohashi Y, Usui M. 1997. Effect of retinol palmitate as a treatment for dry eye: A cytological evaluation. Ophthalmologica 211: 358-361.

5) Ubels JL, Edelhauser HF, Foley KM, Liao JC, Gressel P. 1985. The efficacy of retinoic acid ointment for treatment of xerophthalmia and corneal epithelial wounds. Curr Eye Res 4: 1049-1057.

6) Toshida H, Odaka A, Koike D, Murakami A. 2008. Effect of retinol palmitate eye drops on experimental keratoconjunctival epithelial damage induced by $n$-heptanol in rabbit. Curr Eye Res 33: 13-18.

7) Akiyama H, Sato M, Qiu G, Toida T, Imanari T. 1994. Analytical studies on hyaluronic acid synthesis by normal human keratinocytes cultured in a serum-free medium. Biol Pharm Bull 17: 361-364.

8) Tammi R, Tammi M. 1986. Influence of retinoic acid on the ultrastructure and hyaluronic acid synthesis of adult human epidermis in whole skin organ culture. $J$ Cell Physiol 126: 389-398.

9) Pasonen-Seppanen SM, Maytin EV, Torronen KJ, Hyttinen JM, Hascall VC, MacCallum DK, Kultti AH, Jokela TA, Tammi MI, Tammi RH. 2008. All-trans retinoic acid-induced hyaluronan production and hyperplasia are partly mediated by EGFR signaling in epidermal keratinocytes. J Invest Dermatol 128: 797-807.

10) Tammi R, Ripellino JA, Margolis RU, Maibach HI, Tammi M. 1989. Hyaluronate accumulation in human epidermis treated with retinoic acid in skin organ culture. $J$ Invest Dermatol 92: 326-332.

11) King IA. 1981. Characterization of epidermal glycosaminoglycans synthesized in organ culture. Biochim Biophys Acta 674: 87-95.

12) King IA. 1984. Increased epidermal hyaluronic acid synthesis caused by four retinoids. Br J Dermatol 110: 607-608.

13) Okano Y, Obayashi K, Yahagi S, Kurihara K, Kaburagi S, Kurata Y, Masaki H. 2006. Improvement of wrinkles by an all-trans-retinoic acid derivative, $\mathrm{D}$ - $\delta$-tocopheryl retinoate. J Dermatol Sci Suppl 2: S65-S74.

14) Nakagawa M. 2004. The effect $\mathrm{d}$ - $\delta$-tocopheryl retinoate as anti-aging agent. Fragrance J 281: 40-43 (in Japanese).

15) Sotozono C, Kinoshita S, Kita M, Imanishi J. 1994. Paracrine role of keratinocyte growth factor in rabbit corneal epithelial cell growth. Exp Eye Res 59: 385-392.

16) Honma Y, Nishida K, Sotozono C, Kinoshita S. 1997. Effect of transforming growth factor-beta1 and -beta2 on in vitro rabbit corneal epithelial cell proliferation promoted by epidermal growth factor, keratinocyte growth factor, or hepatocyte growth factor. Exp Eye Res 65: 391-396.

17) Watanabe M, Nakayasu K, Kanai A. 1999. The effect of neurotransmitters on rabbit cornea. Nippon Ganka Gakkai Zasshi (J Jpn Ophthalmol Soc) 103: 356-362 (in Japanese).

18) Wen KC, Lin SP, Yu CP, Chiang HM. 2010. Comparison of Puerariae Radix and its hydrolysate on stimulation of hyaluronic acid production in NHEK cells. Am J Chin Med 38: 143-155.

19) Kondo T, Chichibu K, Usuki H, Matsuura T, Shichijo S, Yokoyama MM. 1991. Rapid assay of hyaluronic acid in serum. Nihon Rinsho Kensa Igaku Gakkai Zasshi (Rinsho Byori Jpn J Clin Pathol) 39: 536-540 (in Japanese).

20) Borenfreund E, Puerner JA. 1984. A simple quantitative procedure using monolayer cultures for cytotoxicity assays (HTD/NR-90). J Tissue Culture Methods 9: 7-9.

21) Borenfreund E, Puerner JA. 1985. Toxicity determined in vitro by morphological alteration and neutral red absorption. Toxicol Lett 24: 119-124.

22) Torishima H, Arakawa H, Matsui S, Watanabe M. 1990. Application of normal human epidermal keratinocytes in serum-free medium as an alternative to the Draize ocular irritating test. AATEX 1: 20-26.

23) Torishima H, Yamamoto R, Watanabe M. 1995. Neutral red assay using normal rabbit corneal epithelial cells grown in serum-free medium as an alternative to the Draize irritation test. AATEX 3: 29-36.

24) Asari A, Miyauchi S, Takahashi T, Kohno K, Uchiyama Y. 1992. Localization of hyaluronic acid, chondroitin sulfate, and CD44 in rabbit cornea. Arch Histol Cytol 55: 503-511.

25) Miyamoto Y. 1998. Synthesis of hyaluronic acid by corneal epithelial cells. Kinki Daigaku Igaku Gakkai Zasshi (Acta Med Kinki Univ) 23: 49-56 (in Japanese).

26) Tsin AT, Lam KW. 1986. Retinyl palmitate hydrolase activity in the bovine retina. Biochem Biophys Res Commun 134: 1209-1214. 
27) Bernal DL, Ubels JL.1992. Retinyl ester hydrolysis in the rabbit lacrimal gland. Curr Eye Res 11: 889-898.

28) Herbert J, Cavallaro T, Martone R. 1991. The distribution of retinol-binding protein and its mRNA in the rat eye. Invest Ophthalmol Vis Sci 32: 302-309.

29) Usui T, Suzuki K, Kaji Y, Amano S, Miyata K, Heldin P, Yamashita H. 1999. Hyaluronan synthase expression in bovine eyes. Invest Ophthalmol Vis Sci 40: 563-567.

30) Sayo T, Sakai S, Inoue S. 2004. Synergistic effect of $\mathrm{N}$-acetylglucosamine and retinoids on hyaluronan production in human keratinocytes. Skin Pharmacol Physiol 17: $77-83$.

31) Sayo T, Sugiyama Y, Takahashi Y, Ozawa N, Sakai S, Ishikawa O, Tamura M, Inoue S. 2002. Hyaluronan synthase 3 regulates hyaluronan synthesis in cultured human keratinocytes. J Invest Dermatol 118: 43-48.

32) Saavalainen K, Pasonen-Seppänen S, Dunlop TW, Tammi R, Tammi MI, Carlberg C. 2005. The human hyaluronan synthase 2 gene is a primary retinoic acid and epidermal growth factor responding gene. J Biol Chem 280: 14636-14644.

33) Kim JE, Kim B, Kim H, Kim H, Lee JD, Kim HJ, Choi KY, Lee SH. 2010. Retinyl retinoate induces hyaluronan production and less irritation than other retinoids. J Dermatol 37: 448-454.

34) Boehnlein J, Sakr A, Lichtin JL, Bronaugh RL. 1994. Characterization of esterase and alcohol dehydrogenase activity in skin. Metabolism of retinyl palmitate to retinol (vitamin A) during percutaneous absorption. Pharm Res 11: 1155-1159.

35) Yan J, Wamer WG, Howard PC, Boudreau MD, Fu PP. 2006. Levels of retinyl palmitate and retinol in the stratum corneum, epidermis, and dermis of female SKH-1 mice topically treated with retinyl palmitate. Toxicol Ind Health 22: 181-191.

36) Randolph RK, Simon M. 1993. Characterization of retinol metabolism in cultured human epidermal keratinocytes. J Biol Chem 268: 9198-9205.

37) Bailly J, Crettaz M, Schifflers MH, Marty JP. 1998. In vitro metabolism by human skin and fibroblasts of retinol, retinal and retinoic acid. Exp Dermatol 7: 27-34.

38) Ubels JL, Edelhauser HF. 1985. In vivo metabolism of topically applied retinol and all-trans retinoic acid by the rabbit cornea. Biochem Biophys Res Commun 131: 320-327.

39) Nezzar H, Chiambaretta F, Marceau G, Blanchon L, Faye B, Dechelotte P, Rigal D, Sapin V. 2007. Molecular and metabolic retinoid pathways in the human ocular surface. Mol Vis 13: 1641-1650.

40) Fagerholm P, Fitzsimmons T, Härfstrand A, Schenholm M. 1992. Reactive formation of hyaluronic acid in the rabbit corneal alkali burn. Acta Ophthalmol Suppl 202: $67-72$.

41) Fitzsimmons TD, Fagerholm P, Härfstrand A, Schenholm M. 1992. Hyaluronic acid in the rabbit cornea after excimer laser superficial keratectomy. Invest Ophthalmol Vis Sci 33: 3011-3016.

42) Asari A, Morita M, Sekiguchi T, Okamura K, Horie K, Miyauchi S. 1996. Hyaluronan, CD44 and fibronectin in rabbit corneal epithelial wound healing. Jpn J Ophthalmol 40: 18-25.

43) Inoue M, Katakami C. 1993. The effect of hyaluronic acid on corneal epithelial cell proliferation. Invest Ophthalmol Vis Sci 34: 2313-2315.

44) Kubo Y, Arimura A, Nakayasu K, Kanai J. 1999. Effect of vitamin A palmitate on the synthesis of mucins in cultured conjunctiva. Nippon Ganka Gakkai Zasshi (J Jpn Ophthalmol Soc) 103: 580-583 (in Japanese).

45) Hori Y, Spurr-Michaud SJ, Russo CL, Argüeso P, Gipson IK. 2005. Effect of retinoic acid on gene expression in human conjunctival epithelium: secretory phospholipase $A_{2}$ mediates retinoic acid induction of MUC16. Invest Ophthalmol Vis Sci 46: 4050-4061.

46) Varani J, Inman DR, Perone P, Fligiel SE, Voorhees JJ. 1993. Retinoid toxicity for fibroblasts and epithelial cell is separable from growth promoting activity. J Invest Dermatol 101: 839-842.

47) Tei M, Spurr-Michaud SJ, Tisdale AS, Gipson IK. 2000. Vitamin A deficiency alters the expression of mucin genes by the rat ocular surface epithelium. Invest Ophthalmol Vis Sci 41: 82-88.

48) Hori Y, Spurr-Michaud S, Russo CL, Argüeso P, Gipson IK. 2004. Differential regulation of membrane-associated mucins in the human ocular surface epithelium. Invest Ophthalmol Vis Sci 45: 114-122. 